\title{
Review: Peran pakan pada kejadian kembung rumen
}

\author{
Article Review: The role of feed on bloat \\ Yanuartono, Sodarmanto Indarjulianto* , Alfarisa Nururrozi, Hary Purnamaningsih, dan \\ Slamet Raharjo \\ Departemen Ilmu Penyakit Dalam, Fakultas Kedokteran Hewan Universitas Gadjah Mada \\ J1. Fauna No.2, Karangmalang, Depok, Sleman. 55281 Yogyakarta
}

Submitted: 12 April 2018, Accepted: 12 July 2018

\begin{abstract}
ABSTRAK: Kembung rumen atau bloat adalah bentuk gangguan pencernaan yang ditandai dengan akumulasi gas yang berlebihan di rumen. Bloat terjadi ketika mekanisme eruktasi terganggu dan laju produksi gas melebihi kemampuan hewan untuk mengeluarkannya. Bloat bisa terjadi dengan sangat cepat karena volume gas berlebihan yang diproduksi di rumen. Bloat dapat diklasifikasikan menjadi bloat primer (frothy/wet bloat) yang berbentuk busa bersifat persisten yang bercampur dengan isi rumen dan bloat sekunder/timpani bloat (free gas/dry bloat) yang berbentuk gas bebas yang terpisah. Tidak ada metode tunggal pada pencegahan kejadian bloat yang dapat diterapkan dalam setiap situasi yang berbeda, tetapi ada metode pengelolaan dalam pencegahan dan pengobatan yang dapat membantu memperkecil risiko. Kejadian bloat di Indonesia cukup tinggi, tetapi tidak pernah ada data yang terdokumentasikan dengan baik. Tulisan ini bertujuan untuk mengulas bloat serta permasalahannya dari sisi pengenalan gejala klinis maupun laboratoris, pencegahan dan pengobatan sehingga diharapkan dapat diimplementasikan oleh teman teman sejawat maupun petugas lapangan untuk mengurangi risiko kerugian petani akibat kemungkinan kematian pada ternaknya.
\end{abstract}

Kata kunci : bloat, rumen, gas, hipoksia, pengobatan

ABSTRACT: Bloat is a form of indigestion characterized by excessive gas accumulation in the rumen. Bloat occurs when the eructation mechanism is disturbed and the rate of gas production exceeds the animal's ability to expelled it. Bloat can occur very quickly due to excessive volume of gas produced in the rumen. Bloat can be classified into a primary bloat (frothy / wet bloat) mixed with rumen and secondary bloat / free bloat (free gas / dry bloat) contents in a separate free gas. There is no single method of preventing bloat events that can be applied in every different situation, however, there are methods of management in prevention and treatment that can help minimize risks. In Indonesia, although the incidence of bloat is quite high, but no data is well documented. This paper aims to review the bloat and problems in terms of understanding the clinical symptoms and the results of laboratory examination, prevention and treatment so that it is expected to be implemented by peers and field officers to reduce the risk of loss of farmers due to possible livestock death.

Keywords : bloat, rumen, gas, hypoxia, treatment

*Corresponding Author: indarjulianto@ugm.ac.id 


\section{PENDAHULUAN}

Bloat atau kembung rumen adalah gangguan sistemik non-infeksius yang mengakibatkan gangguan pada sistem pencernaan ruminansia (Munda et al., 2016). Bloat dapat diklasifikasikan menjadi bloat primer (frothy/wet bloat) yang berbentuk busa bersifat persisten yang bercampur dengan isi rumen dan bloat sekunder/timpani bloat (free gas/dry bloat) yang berbentuk gas bebas yang terpisah dari ingesta (Rasby et al., 2010). Namun, Irsik (2012) mengklasifikasikan bloat secara lebih rinci menjadi 3 yaitu (1) frothy bloat disebabkan oleh pakan yang mengarah ke pembentukan busa yang stabil di dalam rumen (2) free gas bloat disebabkan oleh pakan yang menyebabkan peningkatan produksi gas dan penurunan $\mathrm{pH}$ rumen secara bersamaan (3) free gas bloat karena kegagalan eruktasi akumulasi gas dari penyebab ekstraruminal seperti obstruksi esofagus.

Penyebab paling umum dari kejadian bloat primer pada ternak ruminansia adalah konsumsi pakan leguminosa dan biji-bijian (Merck Veterinary Manual, 2006). Leguminosa penyebab bloat biasanya meliputi alfalfa, sweetclover, red clover, ladino clover, white clover, dan alsike clover (Majak et al., 2003; Merck Veterinary Manual, 2006). Menurut Majak et al. (1995) kejadian bloat primer pada sapi maupun domba di padang penggembalaaan yang disebabkan oleh leguminosa diseluruh dunia semakin meningkat. Lebih lanjut, tingkat kejadian bloat di negara Bangladesh mencapai 9\% Sarker et al. (2013). Laporan oleh Samad (2001) menunjukkan bahwa tingkat kejadian bloat pada sapi mencapai $1,83 \%$ dan kambing 3,98\%. Hasil penelitian oleh Tagesu (2018) menunjukkan bahwa prevalensi bloat primer di daerah Kebele Lencha, Ethiopia sangatlah tinggi yaitu 79,3\% dengan prevalensi kematian sebesar $25,4 \%$. Tingkat kematian akibat bloat di padang penggembalaan ternak dapat mencapai $20 \%$ dan angka kematian pada sapi perah setiap tahun dapat mencapai angka 1\% (Merck Veterinary Manual, 2006). Kejadian bloat di Indonesia cukup tinggi, tetapi tidak pernah ada data yang terdokumentasikan dengan baik. Gejala klinis yang sering teramati adalah adanya pembesaran atau distensi rumen bagian kiri, stress dan dispnu. Gejala lain yang mungkin teramati adalah meningkatnya frekuensi berbaring dan bangun, peningkatan frekuensi defekasi, menendang perut dan berguling untuk mengurangi rasa sakit (Radostits et al., 2010; Aiello and Moses, 2016).

Selain kematian, bloat juga mengakibatkan kerugian ekonomi yang cukup tinggi seperti biaya perubahan strategi manajemen pakan, tindakan pencegahan dan pengobatan (Clarke dan Reid, 1974). Kejadian bloat dapat dicegah dengan berbagai metode mulai dari pencegahan melalui manipulasi pakan sampai dengan pengobatan (McMahon et al., 1999; Digraskar et al., 2012; Rahman et al., 2016). Salah satu metode pencegahan yang dapat adalah dilakukan penggembalaan secara bertahap untuk memperoleh hijauan di padang rumput (Abdullah et al., 2014). Berg et al. (2000) menyatakan bahwa kultivar baru alfalfa mampu menurunkan kejadian bloat sampai 56\%. Pluronic dan poloxalene dapat digunakan untuk mengendalikan kejadian bloat yang disebabkan oleh leguminosa secara efektif (Reid et al., 1961; Stiles et al., 1967; Essig and Shawyer 1968; Miltimore dan Mcarthur, 1970; Clarke dan Reid, 1974). Menurut Majak et al. (1995), berbagai penelitian pencegahan maupun pengobatan dengan menggunakan berbagai bahan seperti suplemen mineral, deterjen dan metode flokulasi, meskipun ternyata bahan bahan tersebut tidak efektif untuk pencegahan bloat terutama bloat yang diakibatkan alfalfa. Pengobatan yang dianggap paling efektif sampai saat ini adalah pemberian simethicone sebagai agen anti pembentukan busa (Birtley et al., 1973; Bernstein and Kasich, 1974; Brečević et al., 1994; Rahman et al., 2016)

Tulisan ini bertujuan untuk mengulas bloat serta permasalahannya secara singkat dari sisi mekanisme terjadinya bloat, pengenalan gejala klinis maupun laboratoris, pencegahan dan pengobatan sehingga diharapkan dapat diimplemen- 
tasikan oleh teman-teman sejawat maupun petugas lapangan untuk mengurangi risiko kerugian petani akibat kemungkinan kematian pada ternaknya.

\section{MEKANISME BLOAT/ KEMBUNG RUMEN}

Ruminansia merupakan poligastrik yang mempunyai lambung depan yang terdiri atas retikulum, rumen, omasum dan abomasum. Rumen dan retikulum memegang peranan penting dalam saluran pencernaan ruminansia. Proses fermentasi pakan terjadi di dalam rumen dan siklus utama motilitas rumen selalu dimulai dengan kontraksi retikulum (Braun dan Jacquat, 2011). Sistem pencernaan pada ruminansia sebagian besar melalui peran mikroba untuk memecah pakan di rumen dan retikulum, aktivitas enzimatik pada abomasum dan usus kecil, serta mikroba di sekum dan usus besar (Sutherland, 1988; Miltko et. al., 2016). Pada ternak ruminansia, mikroorganisme mempenga-ruhi proses fermentasi dalam rumen dan seluruh aspek dari penyerapan makanan oleh ternak (Russel, 1989). Senyawa sederhana berasal dari pencernaan karbohidrat, protein, dan lemak diserap terutama melalui saluran pencernaan bagian depan dan kecil usus (Guilloteau et al., 2009: Hall dan Silver, 2005). Mekanisme pencernaan memiliki hubungan erat dengan kontraksi retikulo rumen (rumen) karena berperan dalam proses pencampuran ingesta serta inokulasi ingesta dengan mikroba (Waghorn dan Reid 1977). Menurut Bost (1970), kontraksi rumen juga berperan dalam mendorong partikel partikel pakan serta mikroba memasuki omasum. Pada sapi sehat, sekitar 30 sampai 50 liter gas dihasilkan setiap jam sebagai hasil fermentasi mikroba dari pakan yang terkonsumsi dan terakumulasi di bagian atas rumen (Bowen, 1996). Secara normal gas di dalam rumen diproduksi secara terus menerus tersebut dapat dieliminasi tanpa kesulitan (Howarth, 1975). Gas yang dihasilkan tersebut kemudian dikeluarkan melalui proses eruktasi atau bersendawa. Eruktasi diinisiasi saat reseptor pada kantung dorsal rumen, area seputar kardia dan persimpangan antar rumen dan esofagus terpapar oleh gas (Weiss, 1953; Broucek, 2014). Menurut Majak et al. (2003) proses eruktasi ini secara normal muncul setiap menit dan memerlukan waktu sekitar 10 detik untuk pengeluaran gas secara keseluruhan. Volume gas yang terbentuk selama proses fermentasi rumen ini meningkat setelah makan dan mencapai puncaknya dalam waktu 2 hingga 4 jam. Hal tersebut mengakibatkan frekuensi eruktasi akan meningkat hingga dapat mencapai 3 hingga 4 kali per menit.

Bloat atau kembung rumen adalah gangguan pada saluran pencernaan ruminansia yang disebabkan oleh retensi gas atau penyimpangan pengeluaran gas dari rumen secara normal. Menurut Merck Veterinary Manual (2006), kembung rumen didefinisikan sebagai pembesaran abdomen karena akumulasi berlebihan dari gas yang terperangkap dalam rumino-retikulum. Kembung terjadi ketika mekanisme eruktasi terganggu atau terhambat dan laju produksi gas melebihi kemampuan ruminansia untuk mengeluar-kannya. Gangguan mekanisme eruktasi tersebut akan mengakibatkan volume gas yang diproduksi oleh rumen berlebihan sehingga kejadian bloat dapat berkembang dengan sangat cepat (Majak et al., 2003).

Bloat dapat diklasifikasikan menjadi bloat primer (frothy/wet bloat) yang berbentuk busa bersifat persisten yang bercampur dengan isi rumen dan bloat sekunder/timpani bloat (free gas/dry bloat) yang berbentuk gas bebas yang terpisah. Lebih lanjut, bloat primer biasanya diklasifikasikan menjadi dua jenis yaitu pasture bloat dan feedlot bloat. Sebagian besar kasus feedlot bloat bersifat sub-akut atau kronis dan terutama terjadi karena pakan pemberian pakan bijian yang tinggi tetapi sedikit hijauan (Wang et al., 2012). Penyebab paling umum dari bloat primer (frothy/wet bloat) adalah konsumsi leguminosa yang berlebihan (Bowen, 2006; Merck Veterinary Manual, 2006). Menurut Fox (2015), bloat sekunder /timpani bloat (free gas/dry bloat) lebih sering dikaitkan dengan atonia rumen atau masalah fisik/patologis yang menghambat eruktasi 
gas secara normal dan kemungkinan disebabkan oleh obstruksi esofagus oleh benda asing. Jika gerak rumen terhambat sebagai akibat pakan bijian yang berlebihan atau karena alasan lain maka bloat sekunder dapat berkembang. Metode untuk membedakan kedua jenis bloat tersebut adalah dengan cara memasukkan stomach tube ke dalam rumen. Jika isi rumen berupa busa maka dalam stomach tube akan banyak ditemukan busa dan gas akan terperangkap di dalamnya maka kejadian tersebut dapat diklasifikasikan ke dalam bloat primer. Namun jika dengan menggunakan stomach tube lokasi kembung mudah ditemukan dan gas dapat keluar melalui tabung disertai dengan hilangnya kembung maka diklasifikasikan ke dalam bloat sekunder (Majak et al., 2003).

Bloat diklasifikasikan menjadi 2 bentuk, yaitu bloat primer dan bloat sekunder, namun demikian pada intinya kejadian bloat merupakan akibat dari gangguan pengeluaran gas secara normal dari rumen. Arti penting dari klasifikasi tersebut terutama berkaitan dengan pencegahan dan pengobatan bloat di lapangan. Salah satu kelemahan di lapangan adalah tidak semua praktisi memiliki stomach tube untuk membeda-kan jenis bloat sehingga hal tersebut dapat mengakibatkan kegagalan dalam pengobatan.

\section{BLOAT PRIMER (FROTHY/WET $B L O A T)$}

Perubahan dalam metode pemberian pakan yang semakin modern mengakibatkan peningkatan kejadian bloat pada ruminansia (Wang et al., 2012). Frekuensi kejadian dan tingkat keparahan bloat primer di padang penggembalaan merupakan akibat dari interaksi berbagai macam faktor seperti jenis ternak, tata kelola ternak dan pakan hijauan yang dipengaruhi oleh kondisi lingkungan area peternakan. Kondisi lingkungan yang dapat mempengaruhi tersebut antara lain adalah temperatur lingkungan, radiasi sinar matahari dan embun (Majak et al., 2003; Min et al., 2005: Min et al., 2006). Kejadian bloat primer pada sapi semakin meningkat di seluruh dunia sebagai akibat dari pem- berian pakan berupa leguminosa yang dibudidayakan di padang rumput dan lahan reklamasi (Majak et al., 2001). Kejadian tersebut biasanya pada sapi yang digembalakan di padang rumput tanaman gandum atau leguminosa seperti alfalfa (Medicago sativa L.), ladino, white clover atau leguminosa yang telah dicacah (Rutter et al., 2004; Rick et al., 2010). Bowen (2006) menyatakan bahwa kejadian bloat primer pada sapi yang dikastrasi disebabkan oleh pemberian pakan leguminosa yang berlebihan seperti alfalfa atau clover yang dengan cepat difermentasi di dalam rumen. Kecepatan peningkatan fermentasi tersebut akan menghasilkan gas yang berlebihan dan partikel pakan halus yang memerangkap gas yang terbentuk.

Frekuensi kejadian bloat primer pada sapi lebih tinggi dibandingkan dengan spesies lain seperti domba atau rusa, dan kerentanan pada setiap hewan sangat bervariasi (Ayre-Smith 1971; Colvin dan Backus 1988). Menurut Jones et al., (1997), bloat primer pada domba jarang terjadi karena domba dianggap memiliki kebiasaan makan yang konservatif. Namun demikian, menurut Colvin dan Backus (1988), domba juga dapat menjadi rentan terhadap bloat primer karena mereka menyukai tanaman clover. Menurut Rutter et al., (2004), ruminansia muda lebih rentan terhadap kejadian bloat primer jika dibandingkan dengan ruminansia dewasa. Hal tersebut diduga karena ruminansia dewasa sudah sering terpapar dan beradaptasi dengan pakan hijauan yang dapat mengakibatkan bloat primer di padang penggembalaan.

Menurut Howarth et al., (1986), ada 3 faktor yang dapat memicu kejadian bloat primer. Pertama adalah pakan protein tinggi yang mudah dicerna sehingga menghasilkan produksi gas yang cepat dan proliferasi populasi mikroba dalam rumen. Faktor kedua adalah partikel halus dari tanaman yang terfragmentasi dan pecahnya kloroplas yang dapat menghambat pelepasan gas dari rumen. Sedangkan faktor ketiga adalah kondisi yang mendukung bagi bakteri dalam rumen untuk menghasilkan eksopolisakarida yang berlebihan sehingga 
berperan dalam pembentukan busa yang stabil. Menurut Majak et al. (2003), faktor mikroba juga berperan dalam stabilitas busa dalam rumen. Produksi mukopolisakarida berlebihan oleh bakteri akan membentuk lendir dalam rumen sehingga meningkatkan viskositas isi rumen. Lebih lanjut Hess (2000) menyatakan bahwa viskositas akan menyebabkan pembentukan gas menjadi busa yang bersifat stabil dan menciri.

\section{BLOAT SEKUNDER (FREE GAS/DRY $B L O A T)$}

Bloat sekunder (free gas/dry bloat) memiliki frekuensi kejadian lebih sedikit jika dibandingkan dengan bloat primer. Bloat sekunder biasanya terjadi karena hewan tidak mampu mengeluarkan gas bebas dalam rumen dan pada umumnya terjadi sangat cepat sehingga penanganan sering terlambat (Majak et al., 2003). Menurut pendapat Moate et al. (1997), pada bloat sekunder cairan rumen tidak mengandung busa dan sedikit atau juga tidak terdapat busa pada rumen bagian depan sehingga kemungkinan ada penyebab lain yang menghambat eruktasi gas. Hal tersebut didukung oleh Cheng et al., (1998) yang berpendapat bahwa penyebab ketidakmampuan mengeluarkan gas tersebut seringkali sulit atau bahkan tidak ditemukan, namun demikian, kondisi tersebut kemungkinan dapat disebabkan oleh obstruksi parsial akibat benda asing, abses ataupun tumor pada esofagus atau adanya gangguan motilitas rumino retikuler. Pembentukan busa yang stabil dalam rumen dapat menyelimuti kardia rumen sehingga menghambat eruktasi gas. Menurut Yami dan Zewdie (2009), ruminansia kadangkadang menelan benda asing yang cukup besar sehingga menghalangi proses eruktasi dan menyebabkan bloat sekunder. Kondisi tersebut sering terjadi pada kambing yang menelan benda asing termasuk kantong plastik (Nugusu et al., 2013). Sebaliknya, menurut Radostits et al. (2007) yang didukung oleh Bakhiet (2008), kejadian menelan benda asing lebih sering terjadi pada sapi dibandingkan dengan domba, hal tersebut kemungkinan disebab- kan karena sapi kurang mampu memilah benda-benda asing dibandingkan dengan domba sehingga sapi lebih mudah menelan benda asing. Frekuensi kejadian bloat sekunder pada hewan dewasa lebih rendah dan lebih sering bersifat akut karena gangguan pada rumen hewan dewasa cenderung lebih cepat dan parah (Whitlock, 1980; Garry, 1996; Wang et al., 2012).

\section{PENYEBAB BLOAT}

Kebutuhan nutrien untuk pertumbuhan dan kesehatan akan lebih terpenuhi jika berbagai jenis hijauan tersedia pada padang rumput maupun kandang (Provenza et al., 2003). Usaha untuk memenuhi kebutuhan nutrien juga dapat dilakukan dengan sistem integrasi dengan tanaman hijauan pakan ternak sebab banyak manfaat yang dapat dihasilkan dari sistem tersebut (Osak et al., 2015). Selain hal tersebut di atas, variasi hijauan memberi kesempatan ruminansia untuk membatasi asupan senyawa sekunder yang berpotensi toksik (Freeland dan Janzen, 1974). Asupan konsentrasi senyawa tersebut dapat menyebabkan berbagai macam penyakit non infeksius seperti bloat atau bahkan kematian pada ternak ruminansia. Kejadian bloat primer pada ruminansia biasanya disebabkan oleh tanaman leguminosa, rumput dan bijian yang mengandung protein terlarut tinggi, lignin rendah serta banyak mengandung dinding sel tumbuhan yang mudah dicerna (Mangan, 1959; Lehmkuhler and Burris, 2011; Wang et al., 2012). Howarth (1975) dan Majak et al. (1995) menyatakan bahwa konsentrasi klorofil yang berasal dari leguminosa dalam rumen berkaitan erat dengan bloat primer. Pencernaan klorofil mengakibatkan kerusakan membran kloroplas dan melepaskan protein terlarut yang dinamakan faktor I dan II dan diyakini sebagai faktor utama terbentuknya busa dalam rumen. Leguminosa sendiri dapat dibagi menjadi 2 yaitu leguminosa penyebab bloat dan leguminosa yang tidak mengakibatkan bloat. Menurut Austin (1981) ada beberapa hipotesis mengapa jenis leguminosa ada yang dapat mengakibatkan dan tidak mengakibatkan kejadian 
bloat. Hipotesis tersebut melibatkan berbagai macam kombinasi faktor seperti tanaman, hewan dan mikroba yang akhirn- ya semua memiliki peran terhadap kejadian tersebut.

Tabel 1. Hijauan penyebab bloat

\begin{tabular}{|c|c|c|c|}
\hline Potensial & Referensi & $\begin{array}{c}\text { Kurang potensi- } \\
\text { al/relatif aman }\end{array}$ & Referensi \\
\hline $\begin{array}{l}\text { Alfalfa (Medicago sa- } \\
\text { tiva L.) }\end{array}$ & $\begin{array}{l}\text { Thompson et al., } \\
2000 \text {, Berg et al., } \\
2000\end{array}$ & $\begin{array}{l}\text { Birdsfoot Trefoil (Lo- } \\
\text { tus corniculatus L.) }\end{array}$ & $\begin{array}{l}\text { Berg et al., 2000, } \\
\text { Christensen et al., } \\
2017\end{array}$ \\
\hline $\begin{array}{l}\text { Sweet clover (Meli- } \\
\text { lotus officinalis) }\end{array}$ & $\begin{array}{l}\text { Olson,1940, } \\
\text { Howarth et al., } \\
1991\end{array}$ & $\begin{array}{l}\text { Sainfoin (Onobrychis } \\
\text { viciifolia Scop.) }\end{array}$ & $\begin{array}{l}\text { McMahon et al., } \\
\text { 1999, Sottie et al., } \\
2014\end{array}$ \\
\hline $\begin{array}{l}\text { Red Clover (Trifolium } \\
\text { pratense L.) }\end{array}$ & $\begin{array}{l}\text { Bailey, 1958, Hall } \\
\text { dan Majak, } 2000\end{array}$ & $\begin{array}{l}\text { Cicer milkvetch } \\
\text { (Astragalus cicer) }\end{array}$ & $\begin{array}{l}\text { Lees et al., 1982, } \\
\text { Acharya et al., } 2006\end{array}$ \\
\hline $\begin{array}{l}\text { ladino clover/white } \\
\text { clover (Trifolium re- } \\
\text { pens L.) }\end{array}$ & $\begin{array}{l}\text { Dougherty, } 1956, \\
\text { McArthur dan Mil- } \\
\text { timore } 1969 \text {, Jones } \\
\text { et al., } 1973\end{array}$ & $\begin{array}{l}\text { Berseem clover (Trifo- } \\
\text { lium alexandrinum L.) }\end{array}$ & Suttie, 1999. \\
\hline $\begin{array}{l}\text { Alsike Clover (Trifoli- } \\
\text { um hybridum L.) }\end{array}$ & $\begin{array}{l}\text { Majak et al., 2003, } \\
\text { Aiello dan Moses, } \\
2016\end{array}$ & $\begin{array}{l}\text { Crownvetch (Coronil- } \\
\text { la varia L.) }\end{array}$ & Wang et al., 2012 \\
\hline $\begin{array}{l}\text { rye grasses } \\
\text { cosecale spp) }\end{array}$ & Berg et al., 2000 & $\begin{array}{l}\text { Fall rye (Secale cere- } \\
\text { ale L.) } \\
\text { lespedeza (Lespedeza } \\
\text { cuneata) }\end{array}$ & $\begin{array}{l}\text { Constable et al., } \\
2017 \\
\text { Gadberry dan Pow- } \\
\text { ell, } 2017\end{array}$ \\
\hline
\end{tabular}

Tabel 1. menunjukkan hijauan yang memiliki potensi tinggi mengakibatkan bloat, kurang berpotensi dan relatif aman untuk dikonsumsi ternak ruminansia. Hijauan lain yang dapat mengakibatkan bloat adalah kochia (Bassia prostrata L.). Menurut (Gadberry dan Powell, 2017), leguminosa asal daerah tropis seperti kudzu (Pueraria sp.) (Nepomuceno et al., 2013), cowpea/kacang tunggak (Vigna unguiculata (L.) Walp.) (Mullen and Watson, 1999), perennial forage peanut (Arachis glabrata) (Bennett et al., 1995) dan alyce clover (Hoveland, 1997) jarang mengakibatkan bloat. Spesies rumput-rumputan atau graminae yang dapat mengakibatkan bloat primer adalah winter wheat atau gandum (Triticum aestivum L.) (Stewart et al., 1981), triticale (Triticosecale sp.) (Mader et al., 1983) dan rumput-rumputan rye atau gandum hitam (Secale sp., dan Lolium sp.) (Berg et al., 2000). Tanaman kochia (Bassia prostrata L.) telah lama ditanam dan digunakan sebagai pakan di padang penggembalaan di Asia Tengah (Harrison et al., 2000; Waldron et al., 2005) dan ternyata tanaman tersebut dapat mengakibatkan bloat primer karena salah satu sebabnya adalah ukuran daun yang kecil sehingga meningkatkan potensi gas dan busa tertahan di dalam rumen. Selain hal tersebut di atas, kemungkinan lain adalah gelembung yang terbentuk selama fermentasi Bassia prostrata L. berukuran kecil sehingga memiliki tekanan internal yang lebih tinggi dibandingkan gelembung berukuran besar (Busaryev et al., 2012; Shenkoru et al., 2015).

Sampai saat ini hanya sedikit atau belum ada data yang menunjukkan bahwa hijauan pakan ternak di Indonesia memiliki potensi menimbulkan kejadian bloat. Penelitian terkait dengan hal tersebut diatas masih sangat sedikit. Bahkan laporan kasus penyebab kejadian bloat kemungkinan juga tidak pernah terdokumentasi dengan baik. Tanaman Indigofera $s p$. saat ini di Indonesia banyak ditanam sebagai hijauan pakan ternak. Meskipun bersifat toksik karena mengandung indospicine, namun 
laporan penelitian menunjukkan bahwa Indigofera $s p$. tidak menimbulkan kejadian bloat (Fletcher et al., 2015). Penelitian toksisitas lamtoro gung (Leucaena leucocephala L.) pada ruminansia menunjukkan gejala klinis akut ditandai dengan hilangnya rambut, terutama di ekstremitas ekor dan penurunan berat badan (Jones et al., 1978). Hasil penelitian tersebut tidak menunjukkan adanya gejala bloat akibat toksisitas lamtoro gung (Leucaena leucocephala L.). Menurut National Academy of Sciences (1979), daun dan polong tanaman turi (Sesbania grandiflora) tidak bersifat toksik untuk ternak.

Tanaman lain yang banyak digunakan sebagai pakan ruminansia di Indonesia adalah singkong. Tanaman singkong dimanfaatkan sebagai pakan baik berupa daun, umbi maupun kulit umbinya (Simbolon et al., 2016). Pada awalnya hidrogen sianida dalam singkong yang bersifat sangat beracun dianggap oleh beberapa ahli sebagai penyebab utama bloat. Namun pendapat tersebut akhirnya dibantah oleh para ahli melalui penelitian-penelitian yang telah dilakukan (Dougherty, 1956). Penelitian tersebut menunjukkan bahwa pemberian hidrogen sianida pada ruminansia tidak menghambat proses sendawa meskipun saat gas tersebut dipompakan ke dalam rumen. Duncan dan Milne (1993) serta Darmono dan Hardiman (2011) menambahkan bahwa daun cassava (ketela) mengandung beberapa komponen sianogenik seperti amigdalin, linamarin dan sebagainya. Bila daun tersebut dikonsumsi berlebihan maka komponen tersebut akan terhidrolisis oleh $\mathrm{H}_{2} \mathrm{O}$ membentuk $\mathrm{HCN}$ yang sangat beracun dan dapat menimbulkan kematian yang mendadak tanpa memperlihatkan gejala kembung atau bloat (Poulton, 1988; Burritt dan Provenza, 2000; Soto-Blanco dan Górniak, 2010).

Sapi perah dengan produksi tinggi yang diberi pakan bijian dalam jumlah yang banyak dilaporkan banyak mengalami kejadian bloat primer. Lebih lanjut, bloat primer banyak ditemui pada sapi yang dipelihara dalam kandang dan diberi pakan bijian yang digiling tetapi dengan pemberian pakan hijauan dalam jumlah yang tidak mencukupi (Blood dan Radostits, 1989). Sedangkan Graber (2012) dalam tulisannya menyatakan bahwa penambahan biji jagung pada pakan sapi jantan yang dikastrasi dapat mengakibatkan bloat. Bani-Ismail et al. (2007) dalam penelitiannya yang dilakukan di Yordania menyebutkan bahwa kejadian bloat yang berulang seringkali terjadi pada sapi perah dewasa karena berbagai permasalahan tata kelola peternakan seperti pemberian pakan basal berupa bijian giling halus berbentuk tepung dan pemberian pakan kualitas rendah berupa jerami atau kurangnya pemberian pakan hijauan berkualitas tinggi.

Pakan dengan kandungan bijian yang tinggi dianggap dapat mengakibatkan terjadinya bloat. Pakan yang mengandung gandum dalam jumlah yang banyak sering dianggap menyebabkan bloat. Konsumsi pakan konsentrat yang berlebihan akan mengakibatkan peningkatan kecepatan fermentasi oleh bakteri rumen, produksi berlebihan asam lemak volatil (VFA), peningkatan asam laktat, dan penurunan $\mathrm{pH}$ dalam rumen. Hal tersebut mengakibatkan kapasitas absorbsi rumen terlampaui, kontraksi rumen terhambat dan terjadi akumulasi gas di rumen bagian dorsal (Irsik, 2010). Namun, penelitian yang dilakukan di Kanada pada sapi yang diberi pakan konsentrat penuh tidak menunjukkan adanya kejadian bloat. Hal tersebut diduga karena konsentrat yang diberikan berbentuk giling kasar. Hasil penelitian tersebut sesuai dengan teori yang menyatakan bahwa kejadian bloat akan meningkat pada ruminansia dengan pemberian pakan konsentrat bentuk halus yang berlebihan (Majak et al., 2003).

Bloat primer yang terjadi akibat pemberian pakan bijian ataupun konsentrat lebih banyak terjadi pada ruminansia yang dipelihara dengan sistem kandang. Hal tersebut kemungkinan disebabkan salah satunya oleh kurangnya pengetahuan peternak dalam tata kelola pemberian pakan. Namun demikian, di Indonesia kejadian bloat akibat pemberian pakan bijian ataupun konsentrat jarang terjadi meskipun sistem pemeliharaan sebagian besar dikandangkan karena kurangnya lahan 
penggembalaan. Salah satu kemungkinan tersebut karena konsentrat yang diberikan adalah dedak gandum atau wheat pollard dan dedak padi atau bekatul. Dedak gandum dan bekatul sampai saat ini dianggap kurang memiliki kemampuan untuk mengakibatkan terjadinya bloat. Peternak di Indonesia juga memiliki kebiasaan untuk menambahkan molasses pada dedak gandum atau bekatul untuk meningkatkan penampilan ternak (Yanuartono et al., 2017). Penambahan molasses tersebut dapat menurunkan kejadian bloat. Menurut Gadberry (2011), ukuran partikel kecil, kandungan pati dan lemak meningkatkan risiko pada pencernaan dan berpotensi besar membuat ketidakseimbangan nutrien. Bentuk pakan bijian giling halus akan meningkatkan luas permukaan pakan yang tersedia untuk pencernaan mikroba sehingga memper-cepat keasaman, proses fermentasi pakan dan produksi lendir oleh bakteri rumen. Mekanisme tersebut akan mengakibatkan peningkatan osmolalitas cairan rumen dan memberikan kontribusi pada peningkatan viskositas serta stabilisasi busa dalam cairan rumen (Hall dan Majak, 1989). Pendapat pendapat tersebut patut dicermati karena dedak gandum dan bekatul yang diberikan adalah partikel berukuran kecil sehingga memiliki potensi mengakibatkan kejadian bloat primer.

Secara umum, pemberian diet lemak pada sapi potong tidak boleh melampaui $6 \%$ bahan kering sehingga pemberian dedak padi harus dibatasi tidak lebih dari 1/3 diet (Hartadi et al., 1997). Sampai saat ini penelitian pengaruh pemberian dedak gandum atau wheat pollard dan dedak padi atau bekatul terhadap kejadian bloat jarang dilakukan di Indonesia sehingga diperlukan penelitian tersebut, baik untuk ruminansia besar maupun kecil. Hasil penelitian tersebut menunjukkan bahwa bloat primer yang terjadi akibat pemberian pakan bijian ataupun konsentrat lebih banyak diakibatkan oleh ketidaktepatan dalam pemrosesan bijian serta tata kelola pemberian sebagai pakan (Owens et $a l ., 1997)$. Oleh sebab itu, pencegahan kejadian bloat lebih ditekankan pada pening- katan pengetahuan peternak dalam hal tata kelola pemberian pakan.

Penyebab bloat sekunder harus dipastikan dengan pemeriksaan klinis secara seksama untuk menentukan penyebab kegagalan eruktasi. Pada ruminansia dewasa, bloat sekunder jarang terjadi tetapi jika terjadi biasanya bersifat akut dan cenderung lebih cepat serta parah (Garry, 1996). Bloat sekunder/timpani bloat (free gas/dry bloat) lebih sering dikaitkan dengan kejadian atonia rumen atau masalah fisik maupun patologis yang menghambat proses eruktuasi gas secara normal. Kejadian tersebut kemungkian akibat pakan konsentrat yang berlebihan, kerusakan nervus vagus, papilloma esofagus limfosarkoma dan benda asing dalam esofagus (Majak et al., 2013; Nishimura et al., 2014; Olaifa dan Oguntoye, 2017). Benda asing yang dapat mengakibatkan obstruksi tersebut antara lain adalah kentang, apel, lobak, dan buah kiwi, bolus, wortel, tomat dan tongkol jagung (Abdisa, 2018). Bahkan di Yordania, benda asing berupa plastik, tali, potongan pakaian dapat ditemukan dalam retikulorumen ruminansia kecil dan mengakibatkan obstruksi (Hailat et al., 1997).

\section{GEJALA KLINIS BLOAT}

Menurut Smith (1998) volume gas dalam jumlah yang besar akan dihasilkan terus menerus melalui proses fermentasi mikroba rumen. Secara normal gas yang terbentuk tersebut dibuang melalui mekanisme sendawa atau eruktasi. Menurut Bani-Ismail et al. (2007) pada tahap awal kejadian bloat, fossa paralumbar sebelah kiri menunjukkan distensi ringan dan bagian abdomen mengalami kembung. Saat proses kembung berlangsung dan terjadi peningkatan tekanan intraabdominal maka distensi di fosa paralumbar kiri menjadi lebih jelas dan ada kemungkinan terjadi penonjolan rektum. Pada kondisi bloat, baik bentuk primer maupun sekunder distensi dari rumen tersebut akan mengakibatkan tekanan pada diafragma rongga dada maupun abdomen sehingga ternak akan sulit bernafas (Colvin dan Backus,1998; Ramaswamy dan Shar- 
ma, 2011). Keadaan tersebut akan membuat frekuensi pernafasan meningkat dan menjadi dangkal serta memaksa hewan bernafas melalui mulut. Gejala klinis lain yang muncul adalah penurunan atau hilangnya nafsu makan dan jika tidak tertangani dengan depat akan mengakibatkan kematian.

\section{PENCEGAHAN DAN PENGOBATAN BLOAT}

Berbagai macam metode untuk pencegahan bloat telah banyak diteliti dan diaplikasikan di lapangan. Di masa mendatang tampaknya masih banyak diperlukan penelitian terutama difokuskan pada faktor pakan atau agen kemoterapi yang memiliki sifat eruktogenik (Moate et al., 1997). Praktek di lapangan menunjukkan bahwa metode tunggal pada pencegahan kejadian bloat sulit diterapkan karena menyangkut berbagai macam aspek yang harus dicermati. Aspek tersebut terutama ditujukan pada tata kelola peternakan menyangkut peningkatan pengetahuan peternak terhadap tata kelola pakan.

Ruffin (1994) menyatakan bahwa tidak ada metode tunggal pada pencegahan kejadian bloat yang dapat diterapkan dalam setiap situasi yang berbeda, namun demikian, ada metode pengelolaan dalam pencegahan dan pengobatan yang dapat membantu memperkecil risiko. Metode penggembalaan untuk mencegah kejadian bloat yang paling umum adalah pengelolaan padang rumput disertai kontrol dalam penggembalaan, pemberian suplemen makanan ringan, dan pemberian agen antibakteri dan anti pembusaan (Clarke dan Reid 1974).

Hasil ulasan oleh Majak et al. (1995) menunjukkan beberapa teori pencegahan bloat akibat mengkonsumsi alfalfa dengan menggunakan suplemen mineral, deterjen, flokulan terbukti tidak efektif. Sedangkan menurut McMahon et al. (1999) dan Min et al. (2006), pencegahan bloat dapat dilakukan dengan menambahkan leguminosa yang mengandung tanin terkondensasi. Metode pencegahan tersebut diatas kemungkinan melalui mekanisme pengikatan protein dalam ru- men oleh tanin terkondensasi sehingga menurunkan stabilisasi gas yang terperangkap busa. Namun, masih diperlukan penelitian untuk mengetahui lebih dalam kemungkinan adanya interaksi antara tanin terkondensasi dengan mikroorganisme dalam rumen dan dampak yang mungkin muncul pada saluran pencernaan bagian belakang. Hasil penelitian Bretschneider et al. (2007) menunjukkan pemberian silase jagung sebelum pemberian alfalfa mampu menurunkan kejadian bloat, meskipun mekanismenya belum sepenuhnya diketahui.

Kemampuan sejumlah feed additives untuk mencegah bloat telah dikemukakan oleh Hall dan Majak (2001). Menurut Hall et al. (1994), penggunaan poloxalene intraruminal sangat efektif dalam mencegah kejadian bloat. Namun bloat akan tetap terjadi ketika poloxalene dicampur dengan molases blok dan diberikan secara bebas (Lauriault et al., 2005). Thomas (2003) dan Stanford et al. (2001) menyatakan bahwa dokter hewan di Kanada menggunakan polyoxypropylenepolyoxyethylene glycol surfactant polymer (PPG) atau campuran alcohol ethoxylate dengan pluronic detergents yang terlarut dalam air untuk pencegahan bloat. Sebagian besar praktisi menyatakan bahwa pemberian simethicone sebagai anti pembentukan busa merupakan metode yang efektif untuk mencegah bloat primer. Simethicone adalah kombinasi dari polydimethylsiloxane dan hydrated silica gel yang diklasifikasikan sebagai agen anti pembentukan busa. Secara fisiologis Simethicone bersifat tidak aktif dan tidak beracun jika diberikan secara oral pada ruminansia (Birtley et al., 1973; Brečević et al., 1994). Sedangkan penggunaan monensin dapat menurunkan kejadian bloat meskipun dalam penelitian selanjutnya ternyata tidak mampu mencegah insiden awal (Hall et al. 2001). Pencegahan dengan menggunakan $\mathrm{NaCl}$ sejumlah $40 \mathrm{~g} / \mathrm{kg}$ yang ditambahkan ke dalam diet juga dapat mencegah kejadian bloat karena $\mathrm{NaCl}$ mampu meningkatkan asupan air dan meningkatkan laju cairan saat melintasi saluran pencernaan (Wang et al., 2012). Penggunaan antibioti- 
ka untuk pencegahan bloat juga telah diteliti dan diterapkan. Antibiotika seperti telah digunakan aureomycin, terramycin, bacitracin, streptomycin, dan penicillin, untuk pencegahan bloat. Dari berbagai macam antibiotika tersebut hanya penicillin yang efektif mencegah bloat dan tidak memiliki dampak buruk ketika diberikan dengan dosis tunggal $300 \mathrm{mg}$ atau kurang (Barrentine et al., 1956). Konsentrat atau pakan bentuk blok yang dicampur dengan antibiotika 75 sampai $100 \mathrm{mg}$ untuk setiap sapi per hari cukup berhasil dalam menurunkan kejadian bloat. Mekanisme penurunan kejadian tersebut tampaknya terkait dengan perubahan mikroflora dalam rumen dan hanya bersifat sementara. Meskipun demikian penggunaan antibiotika haruslah dibatasi karena dikhawatirkan akan mengakibatkan resistensi (Ruffin, 1994; Majak et al., 2003).

Pendekatan terapi bloat bergantung pada kondisi di mana bloat terjadi, bentuk bloat (primer atau sekunder) dan apakah kejadian tersebut mengancam nyawa ternak (Rick et al., 2010). Ada berbagai metode telah digunakan untuk terapi bloat seperti penggunaan senyawa oral atau stomach tube yang pada prinsipnya digunakan untuk menghilangkan akumulasi gas yang terjadi. Prinsip pengobatan bloat pada ruminansia diawali dengan upaya menghentikan proses pembentukan gas dan membantu mengeliminasi gas tersebut. Jika upaya tersebut kurang berhasil maka dapat dipergunakan trokar dan kanul yang digunakan untuk menusuk rumen dalam usaha mengeluarkan gas. Pengobatan harus dilakukan secepat mungkin terutama pada kasus bloat akut dan penggunaan trokar atau kanul merupakan upaya terakhir karena dapat mencegah asfiksia atau perdarahan internal serta kematian ternak (Garry 1990; Ruffin, 1994).

\section{KESIMPULAN}

Bloat dapat diklasifikasikan menjadi bloat primer (frothy/wet bloat) dan bloat sekunder/timpani bloat (free gas/dry bloat). Kejadian bloat dapat dicegah dengan berbagai metode mulai dari pencegahan melalui manipulasi pakan sampai dengan pengobatan. Prinsip pengobatan bloat pada ruminansia adalah upaya menghentikan proses pembentukan gas dan membantu mengeliminasi gas tersebut. Tanaman leguminosa di Indonesia yang umum digunakan sebagai pakan ternak ruminansia relatif aman dan jarang mengakibatkan kejadian bloat meskipun masih diperlukan penelitian yang lebih mendalam terhadap hijauan tersebut guna memastikan keamanannya.

\section{DAFTAR PUSTAKA}

Abdisa, T. 2018. Study on the Prevalence of Bovine Frothy Bloat in and Around Kebele Lencha, Tokke Kutaye District, Oromia Region. Appro Poult Dairy \& Vet Sci, 2(3), 1-10.

Abdullah, F.F.J., Adamu, L., Saad, M.Z., Osman, A.Y., Haron, A.W., Awang, D.N., and Roslim. N. 2014. Concurrent Bloat and Rectal Prolapse in A Cow. International Journal of Livestock Research, 4 (1), 115-160.

Acharya, S. N., Kastelic, J. P., Beauchemin, K. A., and Messenger, D. F. 2006. A review of research progress on cicer milkvetch (Astragalus cicer L.). Can. J. Plant Sci, 86(1), 49-62.

Aiello, S.E., and Moses, M.A. 2016. The Merck veterinary manual. Merck.

Austin, A. R. 1981. Legume use in relation to animal health. Legumes in Grassland: Proceedings of the 5th Study Conference of the Scottish Agricultural Colleges, Auchincruive, Ayr: West of Scotland Agricultural College,

Ayre-Smith, R. A. 1971. Pasture bloat in cattle. Aust. Vet. J, 47(4), 162-169.

Bailey R.W. 1958. Bloat in cattle: X. The carbohydrases of the cattle rumen ciliate Epidinium ecaudatum craw- 
ley isolated from cows fed on red clover (Trifolium pratense L). New Zealand Journal of Agricultural Research, 1(6), 825-833.

Bakhiet, A.O. 2008. Studies on the rumen pathology of Sudanese desert sheep in slaughter house. Sci. Res. Essays, 3(7), 294-298.

Bani Ismail, Z. Al-Majali A., and AlQudah, K. 2007. Clinical and Surgical Findings and Outcome Following Rumenotomy in Adult Dairy Cattle Affected with Recurrent Rumen Tympany Associated with Non-Metallic Foreign Bodies. American Journal of Animal and Veterinary Sciences, 2 (3), 66-71.

Barrentine, B. F., Shawver, C. B., and Williams, L.W. 1956. Antibiotics for the prevention of bloat in cattle grazing Ladino clover. J. Ani. Sci, 15(2), 440-446.

Bennett, L.L., Hammond, A.C., Williams, M.J., Kunkle, W.E., Johnson, D.D., Preston, R.L., and Miller, M.F. 1995. Performance, carcass yield, and carcass quality characteristics of steers finished on rhizoma peanut (Arachis glabrata)-tropical grass pasture or concentrate. Journal of Animal Science, 73(7), 18811887.

Berg, B.P., Majak, W., McAllister, T.A., Hall, J.W., McCartney, D., Coulman B.E., Goplen, B.P., Acharya, S.N., Tait R.M., and Cheng, K.J. 2000. Bloat in cattle grazing alfalfa cultivars selected for a low initial rate of digestion: A review. Can. J. Plant Sci, 80(3), 493-502.

Bernstein, J.E., and Kasich, A.M. 1974. A double-blind trial of simethicone in functional disease of the upper gastrointestinal tract. J. Clin. Pharmacol, 14(11-12), 617-623.
Birtley, R.D.N., Burton, J.S., Kellet, D.N., Oswald, B.J., and Pennington, J.C. 1973. The effect of free silica on the mucosal protective and antiflatulent properties of polydimethylsiloxane. J. Pharm. Pharmac., 25(11), 859-863.

Blood, D. C. S., and Radostits, O. M. 1989. Veterinary Medicine. II: Diseases of Alimentary Tract. Baillière Tindall and Cassal Ltd. pp. 228-287

Bost, J. 1970. Omasal physiology. In: Physiology of digestion and metabolism in the ruminant, Phillipson, A. T. ed., Newcastle-upon-Tyne, Oriel Press. 52-65.

Bowen, R 2006. Pathophysiology of the Digestive System. http://www.vivo.colostate.edu/hboo ks/pathphys/digestion/index.html.

Bowen, R. 1996. Rumen physiology and rumination.

www.vivo.colostate.edu/hbooks/pat hphys/.../rumination.htm.

Braun, U., and Jacquat, D. 2011. Ultrasonography of the omasum in 30 Saanen goats. BMC veterinary research, 7(1), 1-8.

Brečević, L., Bošan-Kilibarda, I., and Strajnar, F. 1994. Mechanism of antifoaming action of simethicone. $J$. Appl. Toxicol, 14(3), 207-211.

Bretschneider, G., Peralta, M., Santini, F. J., Fay, J.P., and Faverin, C. 2007. Influence of corn silage supplementation before alfalfa grazing on ruminal environment in relation to the occurrence of frothy bloat in cattle. Animal Feed Science and Technology, 136(1-2), 23-37.

Broucek, J. 2014. Production of Methane Emissions from Ruminant Husbandry: A Review. Journal of En- 
vironmental Protection, 5(15), 1482-1493.

Burritt, E., and Provenza, F. 2000. Role of toxins in intake of varied diets by sheep. Journal of Chemical Ecology, 26(8), 1991-2005.

Busaryev, O., Dey, T., Wang, H., and Ren, Z. 2012. Animating bubbles interaction in liquid foam. ACM Transactions on graphics, 31(4), 1-8.

Cheng, K. J., McAllister, T. A., Popp, J. D., Hristov, A. N., Mir, Z., and Shin, H. T. 1998. A review of bloat in feedlot cattle. J. Anim. Sci, 76 (1), 299-308.

Christensen, R.G., Eun, J.-S., Yang, S.Y., Min, B.R., and MacAdam J.W. 2017. In vitro effects of birdsfoot trefoil (Lotus corniculatus L.) pasture on ruminal fermentation, microbial population, and methane production. The Professional Animal Scientist, 33 (4), 451-460

Clarke, R., and Reid, C. 1974. Foamy bloat of cattle. A review. J. Dairy Sci., 57(7), 753-785.

Colvin, H. W. Jr., and Backus, R. C. 1988. Bloat in sheep (Ovis aries). Comp. Biochem. Physiol, 91(4),: 635-644.

Constable, P.D., Hinchcliff, K.W., Done, S.H., and Gruenberg, W. 2017. A Textbook of the Diseases of Cattle, Horses, Sheep, Pigs, and Goats Veterinary Medicine. $11^{\text {th }}$ Edition. 3251 Riverport Lane St. Louis, Missouri: Elsevier.

Hess, J.L. 2000. Future of alfalfa as a grazing crop: Bloat. American Forage and Grassland Council. Proceedings. 9, 351-358.

Darmono, dan Hardiman 2011 Penyakit Utama Yang Sering Ditemukan Pada Ruminansia Kecil (Kambing
Dan Domba) (Common Diseases for Small Ruminants Goat and Sheep). Workshop Nasional Diversifikasi Pangan Daging Ruminansia Kecil. 33-38

Digraskar, S.U., Muley, V.D., Ravikanth, K., Dandale, M., and Maini, S. 2012. Therapeutic potential of AFANIL against bloat and for early restoration of rumen function in Bovines. JIVA, 10(3), 15-18.

Dougherty, R.W. 1956. Bloat in Ruminants. Yearbook of Agriculture. https://naldc.nal.usda.gov/downloa d/IND43894642/PDF 108-113

Duncan, A.J., and Milne, J.A. 1993. Effect of oral administration of brassica secondary metabolites allyl cyanide, allyl isothocyanate and dimethyl disulphide, on the voluntary food intake and metabolism of sheep. Britian Journal of Nutrition, 70(2), 631-645.

Essig, H. W., and Shawyer, C. B. 1968. Methods of administration of poloxalene for control of bloat in beef cattle grazing Ladino clover. $J$ Anim. Sci, 27 (6), 1669-1673.

Fletcher, M.T., Al Jassim, R.A.M., and Cawdell-Smith, A.J. 2015. The Occurrence and Toxicity of Indospicine to Grazing Animals. Agriculture, 5(3), 427-440.

Fox, J.G. 2015. Laboratory animal medicine. Elsevier. Journal of the American Veterinary Medical Association, Laboratory Animal.

Freeland, W. J., and Janzen, D. H. 1974. Strategies in herbivory by mammals: The role of plant secondary compounds. Am. Nat, 108(961), 269-289.

Gadberry, S. 2011. Alternative Feeds for Beef Cattle - FSA3047. 
https://www.uaex.edu/publications/ PDF/FSA-3047.pdf

Gadberry, S. and Powell, J. 2017. Nutritional Disorders in Beef Cattle. https://www.uaex.edu/publications/ PDF/FSA-3071.pdf

Garry, F. 1990. Managing bloat in cattle. Vet. Med. agris.fao.org/agrissearch/search.do? recordID $=U S 90$ 45244, 643-650.

Garry, F.B. 1996. Indigestion in Ruminants. In: Large Animal Internal Medicine, 3: 824-858.

Graber, R. 2012. A Difficult Reality to Digest: The Effects of a Corn-Based Diet on the Digestive System of Cattle. Eukaryon, 8, 51-54

Guilloteau, P., Zabielski, R., And Blum, J.W. 2009. Gastrointestinal Tract And Digestion In The Young $\mathrm{Ru}-$ minant: Ontogenesis, Adaptations, Consequences And Manipulations. Journal Of Physiology And Pharmacology, 60(3), 37-46.

Hailat, N., Nouh, S., Al-Daraji, A., Lafi S., AlAni, F., and Al-Majali, A. 1997. Prevelence and Pathology of Foreign Bodies (plastics) in Awassi Sheep in Jordan. Small Rum. Res, 24(1), 43-48.

Hall, J. W., Majak, W., McAllister, T. A., and Merrill, J. K. 2001. Efficacy of Rumensin controlled release capsule for the control of alfalfa bloat in cattle. Can. J. Anim. Sci, 81(2), 281-283.

Hall, J. W., Walker, I., and Majak, W. 1994. Evaluation of two supplements for the prevention of alfalfa bloat. Can. Vet. J., 35 (11), 702705 .

Hall, J.B., and Silver, S. 2005. Nutrition and Feeding of the Cow-Calf Herd:
Digestive System of the Cow. Virginia Cooperative Extension, Virginia Tech.

Hall, J.W., and Majak, W. 2000. Plant and animal factors in legume bloat. Pages 94-106 in P. R. Cheeke, ed. Toxicants of plant origin. Vol. 3: 93-106.

Harrison, R.D., Chatterton, N.J., Waldron, B.L., Davenport, B.W., Palazzo, A.J., Horton W.H., and Asay K.H. 2000. Forage Kochia - Its compatibility and potential aggressiveness on intermountain rangelands. Logan UT: Utah State University. Utah.

Hartadi, H., S. Reksodihadiprodjo, A.D. Tillman. 1997. Tabel Komposisi Pakan untuk Indonesia, Yogyakarta: UGM Press.

Hoveland, C. S. 1997. A Problem ofl luxury and Abundance. georgiaforages. caes.uga.edu/documents/GC9704.p df

Howarth, R. E. 1975. A Review Of Bloat In Cattle. Can. Vet. Jour, 16 (10): 281-294.

Howarth, R.E., Chaplin, R.K., Cheng, K.J., Goplen, B.P., Hall, J.W., Hironaka, R., Majak, W., and Radostits, O.M. 1991. Bloat in Cattle. Agriculture Canada Publication 1858/E. Communications Branch. Agriculture and Agri-Food Canada, Ottawa.

Howarth, R.E., Cheng, K.J., Majak, W., and Costerton, J.W. 1986. Ruminant bloat. In: Milligan, L.P., Grovum, W.L., Dobson, A., (eds.), Control of digestion and metabolism in ruminants. Prentice-Hall, Englewood Cliffs, NJ. USA. 516527. 
Irsik, M.B. 2012. Bloat In Cattle. http://edis.ifas.ufl.edu/vm122. IR00003755/00001

Jones, R.J, Blunt, C.G., and Nurnberg, B.I. 1978. Toxicity of Leucaena leucocephala. The effect of iodine and mineral supplements on penned steers fed a sole diet of Leucaena. Aust Vet J., 54(8), 387-392.

Jones, T.C., Hunt, R, D., and King, N.W. 1997.Veterinary Pathology, 6th ed.. new York, Pennsylvania: Williams and Wilkins.

Jones, W. T., Anderson L. B., and Ross M. D. 1973. Bloat in cattle: XXXIX. Detection of protein precipitants (flavolans) in legumes. New Zealand Journal of Agricultural Research, 16 (3), 441-446.

Lauriault, L.M., Kirksey, R.E., Donart, G.B., Sawyer, J.E., and VanLeeuwen, D.M. 2005. Pasture and stocker cattle performance on furrow-irrigated alfalfa and tall wheatgrass pastures, Southern High Plains, USA. Crop Sci, 45 (1), 305315.

Lees, G.L., Howarth, R.E., and Goplen, B.P. 1982. Morphological characteristics of leaves from some legume forages: relation to digestion and mechanical strength. Can. J. Bot, 60 (10), 2126-2132.

Lehmkuhler, J. and Burris, R. 2011. Managing Legume-Induced Bloat in Cattle. www.ca.uky.edu/agc/pubs/id/id186 /id186.pdf

Mader, T.L., Horn, G.W., Phillips, W.A., and McNew, R.W. 1983. Low quality roughages for steers grazing wheat pasture 1. Effect on weight gains and bloat. J. Anim. Sci., 56 (5),1021-1028.
Majak, W., McAllister, T. A., McCartney, D., Stanford, K., and Cheng. K.J. 2003. Bloat in Cattle. Alberta Agriculture and Rural Development https://www1.agric.gov.ab.ca/\$dep artment/deptdocs.nsf/all/agdex6769.

Majak, W., Hall, J., and McCaughey, W. 1995. Pasture management strategies for reducing the risk of legume bloat in cattle. J.Anim.Sci., 73 (5), 1493-1498.

Majak, W., Hall, J.W., and Mcallister, T.A. 2001. Practical measures for reducing risk of alfalfa bloat in cattle. $J$. Range Manage, 54(4), 490-493.

Mangan, J. L. 1959. Bloat in cattle: XI. The foaming properties of proteins, saponins, and rumen liquor. New Zealand Journal of Agricultural Research, 2(1), 47-61.

McArthur, J.M., and Miltimore, J.E. 1969. Bloat investigations. The $\mathrm{pH}$ of rumen contents and its role in legume bloat. Can. J. Anim. Sci., 49 (1), 59-67.

McMahon, L. R., Majak, W., McAllister, T.A., Hall, J.W., Jones, G.A., Popp, J.D., and Cheng K. J. 1999. Effects of sainfoin on in vitro digestion of fresh alfalfa and bloat in steers. Can. J. Anim. Sci., 79 (2), 203-212.

Merck Veterinary Manual. 2006. <http:www.merckvetmanual.com/ $\mathrm{mvm} / \mathrm{htm} / \mathrm{bc} / 21705$.htm $>$.

Miltimore, J. E., and Mcarthur, J. M. 1970. Bloat Investigations. Prevention With Poloxalene, Tallow Pluronic, And Phosphorus On Alfafa. Can. J. Anim. Sci., 50 (3), 651-656.

Miltko, R., Bełżecki, G., Kowalik, B., and Skomiał, J. 2016. Presence of carbohydrate-digesting enzymes throughout the digestive tract of 
sheep. Turk J Vet Anim Sci., 40(3), 271-277

Min, B.R., Pinchak, W.E., Anderson, R.C., Fulford, J.D., and Puchala, R. 2006. Effects of condensed tannins supplementation level on weight gain and in vitro and in vivo bloat precursors in steers grazing winter wheat. J. Anim. Sci., 84(9), 25462554.

Min, B.R., Pinchak, W.E., Fulford, J.D., and Puchala, R. 2005. Effects of feed additives on in vitro and in vivo rumen characteristics and frothy bloat dynamics in steers grazing wheat pasture. Animal Feed Science Technology, 123-124(2), 615 -629 .

Moate, P. J. Clarke, T. Davis, L. H., and Laby, R. H. 1997. Rumen gases and bloat in grazing dairy cows. Journal of Agricultural Science, Cambridge, 129 (4), 459-469.

Mullen, C. and R.W. Watson. 1999. Summer legume forage crops: cowpeas, lablab, soybeans. NSW Department of Primary Industries. Broadacre crops. Agfact P4.2.16. https://www.dpi.nsw.gov.au/.../broa dacre-crops/foragefodder/crops/summer-legume-.

Munda, S., Pandey, R., Bhojne, G.R., Dakshinkar, N.P., Kinhekar, A.S., Kumar, V., Ravikumar, R.K., and Kumar, V. 2016. Indigenous Knowledge Research System [IKRS] for treatment of bloat and its significance towards greenhouse gas emission: Jharkhand, India. Adv. Anim. Vet. Sci., 4(5), 241-249.

National Academy of Sciences. 1979. Tropical Legumes: Resources for the Future. Washington DC: National Academy Press.
Nepomuceno, D.D., Almeida, J.C.C., de Carvalho, M.G., Fernandes, R.D., and Catunda Júnior, F.E.A. 2013. Classes of secondary metabolites identified in three legume species. R. Bras. Zootec., 42 (10), 700-705.

Nishimura, M., Toyota, Y., Ishida, Y., Nakaya, H., Nishikawa, K., Miyahara, K., Inokuma, H., and Furuoka, H. 2014. Zygomycotic mediastinal lymphadenitis in Beef cattle with ruminal tympany. $J$ Vet Med Sci., 76(1), 123-127.

Nugusu, S., Velappagounder, R., Unaka, C., and Nagappan, R. 2013. Studies on Foreign Body Ingestion and their Related Complications in Ruminants Associated with Inappropriate Solid Waste Disposal in Gondar Town, North West Ethiopia. International Journal of Animal and Veterinary Advances, 5(2), 67-74.

Olaifa, A.K., and Oguntoye, C.O. 2017. Type I free gas bloat vagal indigestion in a 10-month old west African dwarf goat: a case report. Case Study and Case Rep., 7(2), 35-45.

Olson, T.M. 1940. Bloat in Dairy Cattle. Journal of Dairy Science, 23(4), 343-353.

Osak, R.E.M.F., Hartono, B., Fanani, Z., and Utami, H.D. 2015. Profil sistem integrasi usaha sapi perah dengan tanaman hortikultura di Nongkojajar Kecamatan Tutur Kabupaten Pasuruan. Jurnal IlmuIlmu Peternakan, 25(2), 49 - 61.

Owens, F.N., Secrist, D.S., Hill, W.J., and Gill, D.R. 1997. The Effect of Grain Source and Grain Processing on Performance of Feedlot Cattle: A Review. J. Anim. Sci., 75(3), 868-879. 
Poulton, J.E. 1988. Localization and catabolism of cyanogenic glycosides. In: Cyanide Compounds in Biology. 67-91.

Provenza, F.D., Villalba, J.J., Dziba, L.E., Atwood, S.B., and Banner, R.E. 2003. Linking herbivore experience, varied diets, and plant biochemical diversity. Small Rum. Res., 49(3), 257-274.

Radostits, O.M., Gay, C.C., Hinchcliff, K.W., and Constable, P.D. 2007. A textbook of the diseases of cattle, horses, sheep, pigs and goats. Veterinary Medicine. 10th ed. London: Saunders

Radostits, O.M., Gay, C.C., Hinchclitt, K.W., and Constable, P.D. 2010. Veterinary Medicine, a Text Book of the Disease of Cattle, Horses, Sheep, Goats, and Pigs. (10th edn). New York : Elsevier, 1516-1579.

Rahman, M. M., Bhuiyan, M.M.U., Islam, T., and Shamsuddin, M. 2016. Efficacy of simethicone for treatment of bloat in ruminants. Asian J. Med. Biol. Res., 2(4), 635-638.

Ramaswamy, V., and Sharma, R.H. 2011. Plastic bags threat to environment and cattle health: A retrospective study from Gondar city, Ethiopia. Special Issue IIOAB J., 2(1), 7-12.

Rasby, R.J., Anderson, B.E., and Randle, R.F. 2010. Bloat Prevention and Treatment in Cattle. http://www.ianrpubs.unl.edu/pages/ publica-

tionD.jsp?publicationId=1290.

Reid, C.S.W., Johns, A.T., and Vlieg, P. 1961. Bloat in cattle. Further experiments on treatment and prevention. N.Z. J. Agr. Res., 4(5-6), 476-483.
Rick, J.R., Anderson, B.E., and Randle, R.F. 2010. Bloat Prevention and Treatment in Cattle. IANR.1-4.

Ruffin, B.G. 1994. Controlling Bloat in Cattle. Alabama Cooperative Extension System, Pub. ANR-148. USDANRCS. 2010. Conservation Practice Standard: Forage and Biomass Planting-Code 512.

Russel, J. B. 1989. Growth Independent Energy Dissipation by Ruminan Bacteria In : Hoshino, S . Onodera, $R$ : Mimato, R. Itabashi, H . (ed) Tokyo : Japan Scientific Society Press.

Rutter, S.M., Orr, R.J., Yarrow, N.H., and Champion, R.A. 2004. Dietary preference of dairy heifers grazing ryegrass and white clover, with and without an anti-bloat treatment. Applied Animal Behaviour Science, 85(1-2), 1-10.

Samad, M.A. 2001. Observations of clinical diseases in ruminants at the Bangladesh Agricultural University Veterinary Clinic. Bangl. Vet. J. 35, 93-120.

Sarker, M.A.S., Aktaruzzaman, M., Rahman A.K.M.A., and Rah, M.S. 2013. Retrospective study of clinical diseases and disorders of cattle in Sirajganj district in Bangladesh. Bangl. J. Vet. Med., 11(2), 137144.

Shenkoru, T., Faciola, A., Schultz, B., and Perryman, B. 2015. Frothy Bloat (primary ruminal tympany) Potential and Nutrient Content of Forage Kochia (Bassia prostrata L.). Journal of Arid Land Studies. 25(3), 177-180.

Simbolon, N., Pujaningsih, R.I., and Mukodiningsih, S. 2016. Pengaruh berbagai pengolahan kulit singkong terhadap kecernaan bahan kering 
dan bahan organik secara in vitro, protein kasar dan asam sianida. Jurnal Ilmu-Ilmu Peternakan, 26 (1), $58-65$.

Soto-Blanco, B., and Górniak, S.L. 2010. Toxic effects of prolonged administration of leaves of cassava (Manihot esculenta Crantz) to goats. Experimental and Toxicologic Pathology. 62 (4), 361-366.

Sottie, E. T., Acharya, S. N., McAllister, T., Thomas, J., Wang, Y., and Iwaasa A. 2014. Alfalfa Pasture Bloat Can Be Eliminated by Intermixing with Newly-Developed Sainfoin Population. Agron. J., 106 (4), 1470-1478.

Stanford, K., Wang, Y., Berg, B. P., Majak, W., McCartney, D. H., Baron, V., and McAllister, T. A. 2001. Effects of alcohol ethyoxylate and pluronic detergents on the development of pasture bloat in cattle and sheep. J. Dairy Sci., 84(1), 167-176.

Stewart, B., Grunes, D. L., Mathers A. C., and Horn, F. P.1981. Chemical Composition of Winter Wheat Forage Grown Where Grass Tetany and Bloat Occur1. Agronomy journal, 73(2), 337-347.

Stiles, D.A., Bartley, E.E., Erhart, A.B., Meyer, R.M., and Boren, F.W.1967. Bloat in Cattle. XIII. Efficacy of Molasses-Salt Blocks Containing Poloxalene in Control of Alfalfa Bloat. Journal of dairy Sciences., 50(9), 1437-1443.

Sutherland, W.J. 1998. The importance of behavioural studies in conservation biology. Anim Behav., 56(4), 801809.

Suttie, J. M. 1999. Berseem clover (Trifolium alexandrinum). A searchable catalogue of grass and forage legumes, FAO.

http://www.fao.org/ag/AGP/AGPC/ doc/GBASE/data/pf000414.htm

Tagesu, A. 2018. Study on the Prevalence of Bovine Frothy Bloat in and Around Kebele Lencha, Tokke Kutaye District, Oromia Region. Appro Poult Dairy \& Vet Sci. 2(3), 1-10.

Thomas, L. 2003. A new bloat control product hits the market. Cattlemen. June/July 2003. 30.

Thompson, D. J., Brooke, B. M., Garland, G. J., Hall, J. W., and Majak, W. 2000. The effect of stage of growth of alfalfa on the incidence of bloat in cattle. Can. J. Anim. Sci. 80(4), 725-727.

Waghorn, G. C., and Reid, C. S. W. 1977. Rumen motility in sheep and cattle as affected by feeds and feeding. Proceedings on the New Zealand Society of Animal Production, 37, 176-181.

Waldron, B. L., Harrison, R.D., Rabbimov, A., Mukimov, T., Yusupov, S.Y., and Tursvnova, G. 2005. Forage kochia: Uzbekistan's desert alfalfa. Rangelands. 27(1), 7-12.

Wang, Y., Majak, W., and McAllister, T.A. 2012. Frothy bloat in ruminants: Cause, occurrence, and mitigation strategies. Animal Feed Science and Technology, 172(1-2), 103-114.

Weiss, K. E. 1953. Physiological Studies On Eructation In Ruminants. Onderstepoort Journal of Veterinary Research, 26(2), 251-283.

Whitlock, R.H. 1980. Bovine Stomach Diseases. In: Veterinary Gastroenterology (Ed., N.V. Anderson). Phila- 
delphia, Pennsylvania: Lea and Fibeger, 396-432.

Yami, A., and Zewdie, S. 2009. Bloat in sheep and goats: Causes, prevention and treatment. In Technical Bulletin No.31. Ethiopia Sheep and Goat Productivity Improvement Program (ESGPIP) (Eds R.C. Merkel and L.Dawson).

Yanuartono, Y., Nururrozi, A., Indarjulianto, S., Purnamaningsih, H., and Rahardjo, S. 2017. Molasses: dampak negatif pada ruminansia. Jurnal Ilmu-Ilmu Peternakan, 27(2). 25 34. 